\title{
Narodne nošnje na fotografijama Julija Kempfa i "Ateliera Wollner" početkom 20. stoljeća
}

U proučavanju tradicijskoga odijevanja sela Požeštine s kraja 19. i početka 20. stoljeća kao korisnim dokumentarnim izvorom pokazale su se fotografije iz prva dva desetljeća 20. stoljeća koje su snimili Julije Kempf, osnivač Gradskoga muzeja u Požegi i fotografski "Atelier Wollner" u Požegi. Velik dio njihovih fotografija čuva se u Zbirci fotografija i negativa u Gradskom muzeju Požege. Ove su fotografije povijesna slika muških i ženskih nošnji s kraja 19. i prva dva desetljeća 20. stoljeća na kojima se mogu pratiti izgled, promjene i modni utjecaji na tradicijskoj odjeći požeških sela.

Ključne riječi: Kempf, Julije

Gradski muzej Požega

fotografije, narodna nošnja, Požeština, početak 20. stoljeća,

Atelier Wollner

\section{UVOD}

Ovaj članak inspiriran je višegodišnjim istraživanjima tradicijske odjeće Požeštine u kojem su kao dokumentarni izvor nerijetko poslužile fotografije snimljene u prvoj polovici 20. stoljeća, kako one koje se čuvaju u Gradskom muzeju Požega, tako i one u privatnom vlasništvu kazivača na terenu. Osim što su često nadopunjavale i ilustrirale terenska kazivanja i sačuvanu materijalnu građu, fotografije su nerijetko bile i jedini izvor informacija $\mathrm{u}$ istraživanju narodne nošnje ovoga kraja.

Povjesničar Peter Burke upućuje "da su slike, kao i tekstovi i usmena svjedočanstva, nezanemarivi oblik povijesnog dokaza" (Burke 2003: 11). U povijesti odijevanja foto- 
grafija ili slika dobivaju na važnosti kao dokazni materijal. Ona omogućuje praćenje kontinuiteta i promjena u načinu odijevanja određenoga područja (Ibid.: 85). Upravo fotografije snimljene početkom 20. stoljeća dokumentiraju kako je izgledala i mijenjala se tradicijska odjeća Požeštine toga razdoblja. Na ova zapažanja osvrnula sam se prvi put u kratkom prikazu narodne nošnje na fotografijama "Atelier Wollner" (Matoković 2019: 23 - 26) u sklopu izložbe "Korak ispred vremena, Atelier Wollner (1899. - 1934.)". U daljnjem razmatranju ove teme donosim, uz fotografije “Ateliera Wollner", i prikaze tradicijske odjeće na fotografijama odnosno negativima Julija Kempfa snimljenima u prvom desetljeću 20. stoljeća, a koje su pohranjene u Gradskom muzeju Požege.

\section{FOTOGRAFIJE “ATELIERA WOLLNER” I NEGATIVI JULIJA KEMPFA U ZBIRCI FOTOGRAFIJA I NEGATIVA GRADSKOGA MUZEJA POŽEGE}

Među raznim albumima, fotografijama i negativima velike Zbirke fotografija i negativa Gradskoga muzeja Požega čuvaju se fotografije nastale u prvom stalnom profesionalnom požeškom fotografskom "Atelieru Wollner"' zajedno s fotografijama koje je snimio fotoamater Julije Kempf. ${ }^{2}$ Većina fotografija i negativa ove velike među-odjelne zbirke pohranjena je u sklopu Povijesnoga odjela. ${ }^{3} \mathrm{Na}$ fotografijama "Ateliera Wollner" prikazani su građani Požege i stanovnici okolnih sela, mnoge znamenite ličnosti grada, razna požeška društva, predstave, događaji itd. (Domanović 2019: 3). Fotografkinja Cecilija Wollner je vjerojatno bila prva žena u Hrvatskoj koja je izrađivala i fotografije koje su korištene za izradu razglednica. ${ }^{4}$

Etnološki odjel Gradskoga muzeja Požege čuva većinom portretne fotografije ${ }^{5}$ s prikazom požeške narodne nošnje koje su godinama prikupljane u tadašnju Etnografsku zbirku. Fotografska građa je u Odjelu prikupljana nesistematizirano, uglavnom darovima pojedinaca i u manjoj mjeri otkupom. Od 61 prikupljene fotografije 17 ih je snimljeno u “Atelieru Wollner". Uglavnom prevladavaju grupni portreti obitelji, rođaka, prijatelja, zaručnika i manjih skupina ljudi, a vrlo rijetko pojedinaca. Osobe su snimljene najčešće u cijeloj figuri izravno usmjerenoga pogleda prema kameri. Poze portretiranih

1 "Atelier Wollner" prvi je profesionalni i isključivo namjenski sagrađen fotografski atelijer u Požegi, podignut 1899. godine i otvoren u prosincu te godine u Županijskoj ulici (Maringer 2019: 27). Osnovala ga je mlada fotografkinja Cecilija Wollner (1878. - 1942.). Godine 1906. profesionalno i privatno udružila se s fotografom Julijem Davidsonom i otada se nazivu "Atelier Wollner" dodaje natpis "J. \& C. Davidson Požega" (Domanović 2019: 3). Supružnici su se s djecom 1913. godine odselili u Split, a atelijer je nastavio i dalje s radom pod istim imenom. Od 1919. do 1934. godine u vlasništvu je bračnoga para Šterk koji zadržavaju ime "Atelier Wollner" (Ibid.: 9).

2 Julije Kempf (1864. - 1934.), Požežanin, učitelj i pisac, osnovao je Gradski kulturno-historijski muzej (današnji Gradski muzej Požega) u Požegi 1924. godine i bio njegov prvi ravnatelj i kustos.

3 Većina fotografija i negativa pohranjeno je u privremenoj nekadašnjoj Povijesnoj zbirci, dok se manji dio nalazi u ostalim odjelima Muzeja. Dogovorom kustosa fotografije će se voditi u zajedničkoj među-odjelnoj Zbirci fotografija i negativa. Zbirka je još uvijek u procesu obrade zbog dugogodišnjih priljeva velikih donacija u Povijesni odjel.

4 Njezina prva razglednica datirana 1904. godine prikazuje Veliku, mjesto sjeverno od Požege, kao ljekovito kupalište. Neke od njezinih razglednica objavljene su u monografiji Julija Kempfa "Požega, zemljopisne bilješke iz okoline i prilozi za povijest slob. i kr. grada Požege i Požeške županije" iz 1910. godine (Španiček 2019: 18-19).

5 Dio fotografija zahtijeva konzervatorsko-restauratorske postupke. 
su namještene prema uputama fotografa ili fotografkinje, a nošnje svečane. Na većim grupnim portretima okupljeni seljaci stoje i(li) sjede poredani u nekoliko redova jedan do drugoga. Fotografije su snimljene najčešće u formatima posjetnice $(6 \times 9 \mathrm{~cm})$ i kabinet formatu (10 x $14 \mathrm{~cm})$, zatim produljenom formatu malvern $(8,2 \times 12,5 \mathrm{~cm})$ ili u nekom drugom, većem formatu $(17,6 \times 23 \mathrm{~cm})$. Tanke fotografije iz prva dva desetljeća 20 . stoljeća nalijepljene su na kartone često dekorirane u stilu secesije. Neke imaju otisnute logotipove s nazivom atelijera, ${ }^{6}$ a "[na] većini fotografija nastalih u atelijeru Wollner vidljive su pozadine $\mathrm{u}$ vidu oslikanog platna velikog formata s prikazima prirode ili interijera, a nerijetko i neutralne pozadine, kao npr. sivo-bijela" (Maringer 2019: 27). Od atelijerskih rekvizita najčešće je prisutna stolica, ponekad stup ili stalak za cvijeće. Često nije poznato tko su osobe na fotografijama i okolnosti u kojima su se fotografirale, kao ni njihove životne priče, ali se zna da su snimljene u prvom požeškom fotografskom "Atelieru Wollner".7 (Sl. 1)

Popratni podaci u inventarnom programu Zbirke su različiti i za većinu fotografija nepotpuni te potiču na daljnja dodatna istraživanja. Većina fotografija je datirana bilo prema zapisu fotografa ili prema zapisu nekadašnjih vlasnika ili njihovih nasljednika, neke fotografirane osobe su identificirane imenom i mjestom življenja, dok nekoliko fotografija ima samo okvirnu dataciju i mjesto snimanja. Najveći broj fotografija snimljenih u fotografskom "Atelieru Wollner" datiran je u razdoblje između 1910. i 1918. godine, a nekoliko fotografija je datirano prije i poslije toga razdoblja. Fotografije su izrađivane uglavnom za osobnu i obiteljsku uspomenu i kao takve su, često uramljene, ukrašavale sobe svojih vlasnika. Danas su ove fotografije povijesna slika svečanoga odijevanja požeških seljaka jednoga razdoblja. Upravo zahvaljujući "Atelieru Wollner" pojavljuju se početkom 20. stoljeća portretne fotografije stanovnika požeških sela odjevenih u svoju, onovremenu najsvečaniju odjeću, to jest u ono što etnolozi i kulturni antropolozi danas nazivaju narodna nošnja ili tradicijska odjeća (Matoković 2019a: 23-24).

Tijekom toga razdoblja nastaju i fotografije snimljene u samim selima Požeške kotline. Većinu tih fotografija snimio je Julije Kempf prilikom svoga rada na monografiji "Požega, zemljopisne bilješke iz okoline i prilozi za povijest slob. i kr. grada Požege i Požeške županije", tiskane 1910. godine. U svojim memoarima Kempf zapisuje da je nabavio od prijatelja fotografski aparat kojim "se brzo uvježbao snimati slike u formatima 9 x 12 do 18 x 24 cm" (Kempf 1996: 170). S tim aparatom od 1898. do 1910. obišao je požeške gore i doline, sela i gospoštije u društvu prijatelja te je snimio stotine fotografija (Ibid.: 170, 179). Fotografije i negativi na staklu koje je Julije Kempf snimio u tome razdoblju i nešto iza 1910. godine čuvaju se u Povijesnom odjelu u sklopu Zbirke fotografija i negativa. U muzej su pristizali od njegova osnutka (1924.) donacijom samoga Julija Kempfa i kasnijih godina donacijama njegovih potomaka. ${ }^{8}$ Stakleni negativi iz njegove

6 Fotografski kartoni s otisnutim logotipima bili su zaštitni znak fotografa i fotografskoga atelijera. Njihov reklamni karakter i dizajn bili su odraz toga vremena, industrijalizacije i tehničkoga usavršavanja putem kojega su fotografi nastojali postati prepoznatljivi po kvaliteti izrade fotografije (Skuljan 2009: 61).

7 Fotografije koje na kartonu nemaju otisnuti naziv Atelier Wollner na osnovi prepoznatljive pozadine i tipičnim rekvizitima prisutnim na drugim fotografijama "Ateliera Wollner" identificirane su da su snimljene u dotičnom atelijeru. 
ostavštine su podvrgnuti čišćenju ili konzervatorskim zahvatima ${ }^{9}$ u nekoliko faza i svi imaju izrađeni pozitiv. Radi se o želatinskim negativima uglavnom veličine $9 \times 12 \mathrm{~cm}$, $12 \times 16 \mathrm{~cm}, 13 \times 18 \mathrm{~cm}$ i $18 \times 24 \mathrm{~cm}$.

Osim negativa snimanih za potrebe monografije u ostavštini se nalaze i privatni, snimani u krugu obitelji i prijatelja Julija Kempfa, te nešto reportažno-dokumentarnih koji su snimljeni nakon 1910. godine. Izrađene fotografije za monografiju "Požega" nalijepljene su na čisti jednobojni kartonski podložak ili na onaj sa secesijskim ukrasima i često s rukopisnim nazivima. Oko osamsto komada negativa na staklu čine dragocjen dio fundusa Zbirke fotografija i negativa. Na njima (i fotografijama) su snimljene panorame požeških sela (vidi S1. 2) i krajolika, kulturni spomenici, zgrade, seoske i požeške ulice, požeški trgovi, portreti građana i poznatih osoba, portreti obitelji i prijatelja, društvena i kulturna događanja, izleti, procesije, sajmovi, povijesni dokumenti i predmeti... Većina negativa je imala odgovarajuće natpise ili zapise na posebnom papiru, a dio je identificiran usporedbom s drugim fotografijama iz Zbirke i onima objavljenima u Kempfovoj monografiji. Za razliku od fotografskoga "Ateliera Wollner" njegovi snimci nemaju umjetničke i obrtničke visoke kvalitete, ali su neiscrpan dokumentarni izvor onoga vremena.

Fotografije "Ateliera Wollner" te fotografije i negativi Julija Kempfa skenirani ${ }^{10}$ su ili digitalno snimljeni te inventirani u Računalni inventarni program $\mathrm{M}++$. Osobito su kvalitetno digitalno ${ }^{11}$ snimljeni Kempfovi negativi iz zadnje donacije što je omogućilo bolju dostupnost i vidljivost pri njihovoj analizi i obradi na računalu. Tako skenirane i digitalizirane te pohranjene fotografije na postojani medij omogućuju komparativno istraživanje velike količine građe, dostupnije su korisnicima, a ujedno se originalna građa čuva od oštećivanja i stalnoga rukovanja. ${ }^{12}$

\section{OPĆI OSVRT NA NARODNU NOŠNJU POŽEŠTINE}

Narodna nošnja Požeštine oblikovana je u stilu panonske odjeće i pripada tipu paurske ${ }^{13}$ nošnje koja se nosila u nizinskim i prigorskim selima. Na njezino oblikovanje utjecale su

Muzeju od samoga osnutka. Ostale fotografije i negative iz ostavštine Julija Kempfa i njegove obitelji požeškom muzeju su darovali njegovi nasljednici 2009. godine, a naknadno je pronađeno još petsto komada negativa na staklu 2013. godine (Šperanda 2015: 122)

9 Dio negativa je bio dosta oštećen te je na njima izvršeno samo čišćenje. Nekoliko nađenih slijepljenih komada nisu odvajani radi mogućega daljnjeg oštećenja.

10 Sve fotografije nisu kvalitetno skenirane u visokoj rezoluciji, odnosno digitalizirane. Razlog tomu je što se taj proces provodio u različitim vremenskim periodima, provodili su ih ljudi različitih stručnih profila, a i oprema je bila slabije kvalitete.

11 Stakleni negativi digitalizirani su kvalitetnom foto kamerom u visokoj rezoluciji. Snimci su isporučeni u Raw formatu, JPEG formatu generiranom iz REW-a kao RGB pozitivi te kao JPEG RGB pozitivi smanjeni u mjerilo 1:1 na 360 dpi-a (Izvješće o provedenoj digitalizaciji dijela zbirke želatinskih negativa na staklu iz Gradskoga muzeja Požega 2016.).

12 Originalna građa je pohranjena u beskiselinske folije i kutije u muzejskoj čuvaonici čime je zaštićena od nepovoljnih mikroklimatskih uvjeta.

13 Požeški kraj povijesno je pripadao Pauriji, odnosno Banskoj, civilnoj Hrvatskoj, dok je nekoliko sela južno od Orljave bilo u sklopu Vojne krajine - granice, prema kojima i potječu nazivi za paursku i graničarsku nošnju. 
povijesne društvene i političke promjene na ovom području. Krajem 19. i početkom 20. stoljeća zabilježen je nagli porast seoskoga stanovništva izazvan migracijama doseljenika iz Srednje Europe (Karaman 1997: 22-23, Petković 1997: 166) koji su donijeli svoj način odijevanja te zajedno s ubrzanim razvojem tekstilne industrije i utjecajem građanske kulture doprinijeli su promjenama u dotadašnjoj odjeći požeških seljaka. Muška i ženska narodna nošnja starijega tipa izrađivala se od lana da bi ga u drugoj polovici 19. stoljeća razvojem tekstilne industrije i tržišne ponude postupno zamijenila pamučna pređa ${ }^{14}$ koja se ubrzo proširila tijekom prve polovice 20. stoljeća. U prijelazu s upotrebe lana na pamuk "pamuk je postao platno naroda" (Schoeser 2009: 175). Od lanene i smjese lanene i pamučne pređe tkala se žalobna i radna odjeća, dok je pamučno tkanje bilo namijenjeno isključivo svečanom ruhu. ${ }^{15}$ Svakodnevna odjeća bila je od domaćega platna bez ukrasa ili već iznošena svečanija nošnja. Karakteristično osnovno sastavljeno ruho od tkanih pola bilo je još u živoj upotrebi krajem 19. i početkom 20. stoljeća, kada je narodna nošnja počela preuzimati elemente građanske odjeće i obuće te modne dodatke toga vremena (Matoković 2019b: 18). ${ }^{16}$ Osnovno žensko ruho, oplećak i krila, izrađeni od domaćega tkanog platna ostalo je nepromijenjeno sve do sredine 20. stoljeća dok su ostali dijelovi ženske nošnje: zaprega, rubac ili rida ${ }^{17}$ postupno zamjenjivani od sredine 19. stoljeća manufakturnim maramama i pregačama od kašmira, pamuka i svile. Stariji tip ženske odjeće, bijela krila sa zapregom i tkanim rupcima, zadržala se početkom 20. stoljeća još u nošnji starijih žena, a u korotnoj odjeći sve do sredine 20. stoljeća.

Oplećak je kao ženska gornja košulja bio sastavljen od tkanih pola s dugim i širokim rukavima izrađenima od raznovrsnoga tkanja, ${ }^{18}$ nabran oko vrata i okrugloga vratnog izreza. Osim tkanja, rukavi su često bili ukrašeni i raznovrsnim ručnim radom. ${ }^{19}$ Početkom 20. stoljeća kupovne ili šivane bluze od kupovnih tkanina po uzoru na gradsku modu počele su postupno zamjenjivati oplećak, da bi ga pred Drugi svjetski rat potpuno istisnule (Matoković 2019b: 22). Krila ili skuti ${ }^{20}$ kao donji dio ženske odjeće, odnosno suknje, krajem 19. i u prvom desetljeću 20. stoljeća bila su dugačka gotovo do gležnja. Pod utjecajem nove građanske mode postupno su se skraćivala do pred Drugi svjetski

14 Do sredine 19. stoljeća strojno predene pamučne pređe i platna zapadnjačke industrije distribuirane su na globalnoj razini (Schoeser 2009: 156).

15 Svoju odjeću seljaci požeškoga kraja nazivali su roba ili ruvo. Karakteristika požeške svečane nošnje bila je posebna svijetloplava boja koja se dobivala upotrebom plavila za rublje. Na osnovu toga je i nastao izraz za tu boju požeško plava koja se doduše ne vidi na monokromnim fotografijama s početka 20. stoljeća. Od nošnje zaplavljivala su se ženska krila, oplećci i rupci te muške rubine i gaće.

16 U novinskom članku iz 1892. godine učitelj iz sela Kaptol komentira, uspoređujući s nekadašnjom seljačkom odjećom iz kućne radinosti, tadašnje luksuzno odijevanje seljaka na svetac koji obuva čizme ili s cugom cipele, crne čohene hlače, crni prsluk i kaput, a u ustima cigarnšpic i cigara. Dok za djevojke ili žene piše da niti jedna nije bez svilenoga fertuna i marame, zatim raznoga nakita, broševa, đerdana, narukvica, finih cipela... (Vudy 1892: 1)

17 Naziv rida za tkanu maramu koristio se u nekoliko prigorskih sela Požeštine.

18 Svečani oplećci bili su tkani uzorkovanim tkanjima tipa usniva, krupnog rocanca i ulaganjem. Ova vrsta tkanja bila je prisutna i na ženskim krilima, kao i na rukavima muških košulja i nogavicama gaća.

19 Rasplitom ili prošavom, izrezancem, vezom, perlicama, kukičanom čipkom - ekljom, šlingom... (vidi u Matoković 2019: 20-21).

20 Stariji naziv za suknju, krila, upotrebljavao se uglavnom u prigorskim selima dok se noviji naziv skuti upotrebljavao u nizinskim selima i kod Srba. 
rat. Prednja strana krila tkana od čistoga lošijeg platna, opasivala su se zapregom ili fertunom. Stražnja strana svečanih krila bila su sitno faltana, ukrašena i vidljiva. Svečana krila starijega tipa ženske nošnje bila su bijela krila, ${ }^{21}$ a razlikovala su se prema ukrasnim tehnikama. Preko njih se opasivala zaprega pravokutnoga oblika, tkana od domaće vune i ispunjene raznobojnim prugama te ukrašena raznobojnim resama na krajevima. Takva pregača nosila se samo uz bijela krila. Krajem 19. stoljeća u modu ulaze krila s tkanom zatkom ${ }^{22}$ ili šarom u boji i zadržavaju se sve do kraja uporabe narodne nošnje. Najstarije su bile crvene i crne zatke ukrašene raznobojnim prugama $\mathrm{u}$ bijeloj, plavoj, crnoj ili crvenoj boji, a nošene su kao dio svečane ženske odjeće krajem 19. i početkom 20. stoljeća. Kao novi tip ženske narodne nošnje krila sa zatkom nošena su samo uz pregače od kupovnih industrijskih tkanina zvane fertuni.

Prvotno su se nosile tkane marame zvane rupci ili ride. Gizdavi rupci od finoga pamuka uzorkovanoga tkanja s različitim bijelim ručnim radom nošeni su uz bijela krila i vunenu zapregu. Nošeni su oko vrata i kao marame zavijače preko poculica na glavama udanih žena. Vrlo rano, u modu su ušle kupovne marame od tanke vune s cvjetnim uzorkom, šafolke ili tibetke koje su nošene paralelno s rupcima uz stariju vrstu ženske nošnje, bijela krila i zapregu, ali i poslije uz novi tip, krila sa zatkom i fertunom od istovrsne kašmirske tkanine, ili od manufakturne pamučne ili svilene tkanine. Svečane marame od različitih kupovnih tkanina nošene su na krila s tkanom zatkom uz odgovarajuću vrstu fertuna. Najcjenjenije su bile velike svilene marame zvane svilenke od atlas svile s cvjetnim ukrasom uokolo. (Sl. 4)

Muška narodna nošnja Požeštine u usporedbi sa ženskom nošnjom manje se mijenjala, ali je nakon 1918. godine brzo zamijenjena građanskim odijelom. Košulja ${ }^{23}$ i gaće od domaćeg tkanja nošene su u svim godišnjim dobima kao osnovno muško ruho. Drugi dijelovi odjeće poput prsluka - frosluka i šešira - kape bili su najčešće kupovni. Prsa svečanih muških košulja uvijek su bila izrađena i ukrašena raznovrsnim ručnim radovima ${ }^{24}$ i ukrasnim pucetima, a najsvečanija i raznobojnim perlama. Na košulji pred Prvi svjetski rat u modu ulaze raznobojne satenske vrpce provučene ispod izrezanoga platna u obliku romba i ukrasi od nazubljenoga platnenog ruba. Gaće kao svečane široke muške hlače stegnute uzicom u struku, često su bile ukrašene u donjem dijelu različitim uzorkovanim tkanjima i ručnim ukrasnim tehnikama. ${ }^{25}$ Pod utjecajem gradske mode krajem 19. stoljeća mlađi muškarci postepeno zamjenjuju gaće kupovnim hlačama od čoje, štofa, samta i drugih kupovnih tkanina tada dostupnih na tržištu.

21 Najzastupljenija su bijela krila s krpama, odnosno ukrašena s apliciranim platnom. Ona su se kao i šlingana krila nosila i uz svilene fertune na najveće svece, poput Tijelova i kao dio mladenkine oprave.

22 Zatke su bile tkane od pamučne pređe u boji zvane natak ili mavez tehnikom jednoziva ili jednožica dužine 35 do $50 \mathrm{~cm}$, a razlikovale su se po tehnici i načinu izrade ukrasa.

23 Muška košulja još se nazivala rubina.

24 Većinom su to bile tehnike veza i čipke kao i na rukavima ženskih oplećaka (vidi u Matoković 2019: 29-30).

25 Tkanja su bila slična kao i na ženskom osnovnom ruhu: rocanac, ulagano i borano tkanje, kao i ukrasne tehnike poput prošava, izrezanca, šlinge. 


\section{NARODNA NOŠNJA NA FOTOGRAFIJAMA}

Tijekom opsežnoga i sustavnoga proučavanja tradicijske odjeće požeškoga kraja zadnjih dvaju desetljeća ${ }^{26}$ javljao se problem u istraživanju ove teme za period krajem 19. i početkom 20. stoljeća. Zbog velikoga vremenskog razmaka od stotinjak godina nije bilo više moguće naći direktnoga kazivača za to razdoblje kao i dijelove odjevnih predmeta. ${ }^{27}$ Tijekom 20. stoljeća zbog promjene mode, a pogotovo poslije Drugoga svjetskog rata zbog nepovoljne ekonomske situacije i nedostatka tekstila dijelovi nošnje su se prodavali i prekrajali te samim time i nestajali. U nedostatku toga kao korisnim dokumentarnim izvorom pokazale su se upravo fotografije požeških seljaka u njihovoj odjeći, s početka 20. stoljeća, koje su snimili Julije Kempf te fotografski "Atelier Wollner" u Požegi.

Na prijelazu iz 19. u 20. stoljeće fotografija prati snažne promjene u modi (Simončić 2013: 428). Isto tako mogu se pratiti promjene i preslojavanje u požeškoj narodnoj nošnji na fotografijama u prvim dvama desetljećima 20. stoljeća. U odjeći se sve više prihvaćaju građanski elementi koji se prilagođavaju "seoskoj modi" (Toldi 2009: 15). Umjesto domaćega tkanog oplećka nose se bluze građanskoga kroja šivane od industrijskih tkanina (Ibid.) ili se domaća rubina preslojava građanskim odijelom. Nova moda na nošnji donosi umetnute čipke, vrpce - pantljike, raznobojne perlice - đerdane i ukrasna dugmeta - puceta. Pamučni i svileni fertuni ukrašeni su naborima, volanima, prišivenim vrpcama. Nose se visoke cipele s petom ili lakirane niske cipele. Bogati mlađi muškarci svoje bogatstvo pokazuju džepnim satom na lancu (Sl. 5), a kicoše se leptir mašnama privezanim oko vrata na rubini.

Odabrane fotografije iz Zbirke fotografija i negativa prikazuju uglavnom svečane muške i ženske nošnje novijega tipa ${ }^{28}$ s kraja 19. i prva dva desetljeća 20. stoljeća. Slojevite promjene u odjevnim predmetima stanovnika sela, pogotovo kod mlađe populacije, osobito su vidljive na grupnim portretima većih skupina ljudi, bilo snimljene u fotografskom atelijeru ili one reportažno-dokumentarno snimljene "na licu mjesta", u procesiji, na sajmu, na ulici...

Kao ilustrativni primjer ${ }^{29}$ tih promjena može poslužiti jedna od fotografija snimljenih u "Atelieru Wollner" iz 1907. godine. ${ }^{30}$ (Sl. 6) Snimljena fotografija podsjeća na žanr - scenu gostionice te nije poznato kojim povodom je snimljena i tko su ljudi na fotogra-

26 Terenska istraživanja provođena su u sklopu višegodišnjega istraživačkog projekta (2001. - 2015. godine) kojim se istraživalo tradicijsko odijevanje stanovništva s prostora zapadne Slavonije pod vodstvom Vesne Kolić Klikić iz Gradskoga muzeja Nove Gradiške. Tada je sva prikupljena građa obrađena i cjelovito predstavljena u dvjema monografijama (Kolić Klikić, Vesna 2007. i Kolić Klikić, Vesna 2015.).

27 Doduše postoje prijašnja etnografska istraživanja (koja su uključena u projekt) u kojima su tada sudjelovali kazivači rođeni u 19. stoljeću, kao i malobrojna prijašnja etnološka literatura (Lechner 1977: 301-308) za to razdoblje, ali ona su bila ograničena na pojedina požeška sela. Također treba uzeti u obzir i kazivanje generacije kazivačica rođenih neposredno iza Prvoga svjetskog rata jer je većina imala nekakva znanja o nekadašnjem odijevanju generacije njihovih majka i baka.

28 Pod novijim tipom nošnje podrazumijevam preslojeno osnovno ruho ženske i muške nošnje kupovnim tvorničkim materijalima.

29 U daljnjem pregledu fotografija izdvojen je samo mali broj jer ih je nemoguće sve prezentirati.

30 Fotografija je često korištena kao ilustracija požeške narodne nošnje u monografijama i katalozima izložbi na temu odijevanja. 
fiji u požeškoj narodnoj nošnji. Od četvero ljudi odjevenih u svakodnevnu građansku odjeću jedino ime zabilježeno na poleđini kartona fotografije je ono Požežanina Jakoba Fabijana, ${ }^{31}$ gostioničara i tvorničara soda vode koji stoji u sredini zadnjega reda. Njegova povezanost s portretiranom grupom seljaka u svečanoj narodnoj nošnji i prigoda nastanka snimke zasada ostaje nepoznata. Pretpostavljam da je evociranje žanr-scene gostionice možda povezano sa zanimanjem samoga Jakoba Fabijana, ali moguće je i da se radi o nekoj proslavi. Šarolika skupina ljudi poredanih u nekoliko redova ispred stola s kriglama piva prikazuje muškarce i žene mlađe i starije dobi. Muškarci (osim dvojice) su odjeveni u tipičnu svečanu nošnju: košulju, gaće, prsluk, šešir i u varijantu gdje su tradicijske gaće zamijenjene građanskim hlačama. Od žena i djevojaka u nošnji starije su žene zadržale kao dio oglavlja domaće bijele rupce dok su djevojke i mlađe žene na osnovno ruho preslojile marame i pregače od različitih tvorničkih tkanina. Kod ovakvih fotografija većih skupina ljudi često se može uočiti raznovrsnost u prikazu tradicijske odjeće. Pri tome je jasno uočljiva dobna starost, odjeća mlađih žena i muškaraca više je ukrašena i preslojena "novim modnim dodacima", dok su starije generacije pak jednostavnije odjevene i često zadržavaju dijelove starijega tipa nošnje. ${ }^{32}$

Tijekom prije spomenutoga istraživanja ženskoga i muškoga odijevanja na području Požeštine koristile su se fotografije i negativi s početka 20. stoljeća osim kao ilustracija i za nadopunu i pojašnjenja terenskim istraživanjima. Na jednom terenskom istraživanju 2008. godine slučajno je pronađen rijedak primjerak muškoga odjevnog predmeta koji pripada odjevnom inventaru 19. stoljeća. Radi se o kabanici s velikim ovratnikom i lažnim rukavima od bijeloga sukna. ${ }^{33}$ Ona se doduše spominje u prijašnjoj literaturi, ${ }^{34}$ ali bez podrobnijega opisa. Tijekom daljnjega istraživanja ovaj odjevni predmet potvrđen je u kazivanjima svega troje kazivača. ${ }^{35}$ Prilikom analize digitaliziranih Kempfovih negativa na jednom panoramskom prikazu požeškoga sajma iz 1906. godine uočen je isti tip kabanice na jednom muškarcu. Ovaj slikovni prikaz je potvrdio kazivanje da su kabanicu muškarci odijevali i prigodom odlaska na sajam. ${ }^{36} \mathrm{U}$ ovom slučaju se iz različitih izvora uspjela dobiti cjelovita slika izgleda i uporabe jednoga odjevnog predmeta.

Zahvaljujući fotografijama s prikazom narodnih nošnji može se potvrditi i(li) detektirati način odijevanja pojedinih dijelova nošnje, to jest njihova odjevna kombinacija, pa čak i vremenski datirati njihovo nošenje. U požeškom muzeju čuvaju se starije inačice ne-

31 Na temelju druge fotografije (inv. br. E 973) identificirana je starija ženska osoba u građanskoj odjeći (u zadnjem redu lijevo) kao supruga Jakoba Fabijana.

32 Snimljene osobe na fotografiji su poredane u više redova u sjedećoj (središnji dio) i stajaćoj pozi te se ne vidi kod svih cijela figura, a time i odjevna kombinacija.

33 Kabanica je, kao jedini takav sačuvani primjerak, darovana Etnološkom odjelu Gradskoga muzeja Požege.

34 Julije Kempf spominje kabanicu u svojoj monografiji 1910. godine kao jedan od proizvoda požeških krojača (Kempf 1910: 453), dok Zdenka Lechner u tekstilnim rukotvorinama požeškoga kraja ipak donosi kratki navod njezina izgleda i funkciju (Lechner 1977: 308).

35 Kazivačice su podrijetlom povezane s mjestom u kojem je kabanica pronađena i svi je se sjećaju kao odjevnoga predmeta najstarijih muškaraca u selu između dva svjetska rata. Prema sjećanju jedne od njih nosili su je i prilikom odlaska na sajam.

36 Za razliku od prijašnjih istraživanja Zdenke Lechner, koja kabanicu navodi isključivo kao radni odjevni predmet nošen na pašnjaku uz stoku (Lechner 1977: 308), naši kazivači je stavljaju u oba konteksta, nošenu i na pašnjaku, ali i prilikom odlaska na sajam. 
koliko oplećaka koje na prsima imaju izrezan dio tkanja ukrašenoga čipkom s jednom ili dvjema rupicama. Terenskim istraživanjima je utvrđeno da su se kroz te proreze provlačili krajevi marame nošene na ramenima. Ova inačica odijevanja oplećka inače je uočena i kao sitan detalj na dvama pozitivima snimljenima s Kempfovih negativa iz razdoblja prije 1910. godine.

Jedan od zanimljivih primjera je i rijetko sačuvani fertun od pamučnoga tvorničkog tkanja (Sl. 7) i fotografija (Sl. 8) koja ilustrira takvu vrstu pregače. Naknadnom obradom predmeta ustanovljeno je da su u Muzej došli iz istoga izvora. ${ }^{37}$ Prema inventarnom zapisu $^{38}$ crvena pamučna pregača tvorničkoga krep tkanja s utkanim, okomitim raspoređenim crvenim cvjetovima i žutima prugama bila je vlasništvo portretirane žene na spomenutoj fotografiji. Monokromna fotografija prikazuje portret majke s kćerkom. Žena je odjevena u šivanu bluzu od kupovnoga materijala s plastronom preko koje je zavezana svilena marama s resama. Na krila (koja se ne vide) privezana je pamučna pregača istovjetnoga uzorka, samo u suprotnim bojama ${ }^{39}$ od onih na sačuvanoj pregači. Na glavi, kao znak udane žene, nosi maramu podvezu s poculicom. ${ }^{40} \mathrm{Na}$ temelju zapisa ${ }^{41}$ na poleđini fotografskoga kartona doznajemo da je fotografija snimljena 1916. godine. Vjerojatno je vlasnica posjedovala dvije pregače istovjetnih motiva samo u različitim bojama. ${ }^{42} \mathrm{Na}$ temelju fotografije možemo pretpostaviti odjevnu kombinaciju u kakvoj se sačuvana pregača mogla nositi i okvirno u kojem razdoblju je bila u modi, a to je drugo desetljeće 20. stoljeća. ${ }^{43}$ Iako je često u usmenim terenskim kazivanjima naglašavano da su se u sklopu narodne nošnje odijevale marama i pregača od istih vrsta kupovnih materijala, ${ }^{44}$ ova fotografija ilustrira da su u odjevnoj kombinaciji mogle biti i dvije različite tkanine. U ovom slučaju to su marama od svilene i pregača od pamučne tkanine.

Fotografije "Ateliera Wollner" i Julija Kempfa s početka 20. stoljeća svjedoče da su se djevojke uz svoju svečanu odjeću češljale u višestruku pletenicu zvanu perčin. Genera-

37 Fotografija je prvotno bila uvedena u sekundarnu dokumentaciju Fototeke Etnografske zbirke, dok je pregača bila inventirana kao predmet u Etnografskoj zbirci 1987. godine. Oba predmeta u Muzej su dospjeli iz istoga izvora, od unuke portretirane žene na fotografiji.

38 U računalnom invetarnom programu $\mathrm{M}++$ + Gradskoga muzeja Požege pregača je uvedena pod inventarnim brojem E 967 u sklopu Zbirke narodnih nošnji. Podaci su prepisani iz Knjige inventara Etnografske zbirke VII u kojima je zapisano prema kazivanju zadnje vlasnice predmeta ime i prezime prvobitne vlasnice pregače (radilo se o njezinoj baki) koja ju je odijevala kao dio svoje svečane nošnje. Isto ime i prezime zabilježeno je i za portretiranu ženu na fotografiji inventiranoj pod brojem 13506 u Zbirci negativa i fotografija.

39 Zbog monokrone fotografije boje nisu jasne, ali cvjetni motivi su u svjetlijoj, vjerojatno žutoj boji, dok su pruge najvjerojatnije crvene boje.

40 Ženska kapica zvana pocul(i)ca ili poculjica, najčešće vezena raznobojnom vunicom, pripada starijem sloju tradicije pokrivanja kose kod žena. Nosila se i uz oplećak i bijela krila sa zapregom, ali i uz (kako nam prikazuje ova fotografija) krila s fertunom i bluzom od kupovnih tkanina. Na pocul(i)cu, nad čelom se podvezivala marama složena u traku od tanke vunene ili svilene tkanine zvana podveza.

41 Ponekad se na poleđini prilijepljenoga kartona s fotografijom može uočiti rukopisni zapis fotografa rednoga broja snimka, godine i broj komada izrade fotografije atelijera.

42 Imućnije žene i djevojke posjedovale su i po nekoliko svečanih pregača od kupovnih materijala.

43 Na nekoliko fotografija u privatnom vlasništvu snimljenima u razdoblju Prvoga svjetskoga rata uočene su kupovne pregače od sličnoga pamučnog tkanja s istim rasporedom motiva, u kombinaciji okomitih cvjetova i ravnih linija ili samo valovitih i ravnih linija. 
cije kazivača rođene nakon Prvoga svjetskog rata ne pamte svuda jednako djevojački perčin koji se prestao nositi iza 1920. godine. Sjećaju ga se u nekoliko prigorskih sela Požeštine jer su ga starije žene plele za potrebe nastupa lokalnih folklornih društava. Često su to bili perčini od tuđih kosa ili kudjelje koji su se samo pričvrstili na glavu. Drugi ih pamte po pričama starijih ili po obiteljskim fotografijama s početka 20 . stoljeća. Danas ga rijetko tko zna pravilno isplesti. I u sjećanjima je zapamćena samo jedna verzija češljanja prednjega dijela frizure: s coklinima ${ }^{45}$ i kintošima. ${ }^{46}$ Međutim, prema fotografijama primjećuje se da su postojala raznovrsna djevojačka začešljavanja prednjega čeonog dijela frizure, od tradicijskih coklina i rogova, ${ }^{47}$ ili glatko začešljanoga razdjeljka do visoko nadignute kose nad čelom po uzoru na građanske frizure. (Sl. 9 i 10) Također se primjećuju raznovrsne kombinacije perčina koji viri iznad stražnjega dijela glave s manjim pletenicama pletenima sa strane: kintošima i rocama. ${ }^{48}$ Prilikom rekonstrukcije ${ }^{49}$ djevojačkih frizura s početka 20. stoljeća za potrebe istraživanja i izložbe o djevojačkim i ženskim oglavljima Požeštine 2011. godine korištene su upravo fotografije "Ateliera Wollner" i Julija Kempfa.

Na fotografijama je vidljivo da su se perčini ukrašavali prirodnim cvijećem i zelenilom ili umjetnim cvijećem od svile ili voska. Osim toga ukrašavali su se i raznim špangicama, ukosnicama i drugim kupovnim ukrasima po uzoru na gradsku modu koji se ne mogu na fotografijama uvijek jasno razaznati. Uz to na pojedinim fotografijama također se može uočiti kao zanimljiv detalj nakit kakav su nosile žene i djevojke, ali i muškarci kao dio svojega svečanog odijevanja. ${ }^{50}$ (vidi Sl. 1, 4, 9 i 10) Zahvaljujući ovim fotografijama rekonstruirane ${ }^{51}$ su ogrlice od raznobojnih perlica kojih se više nije moglo naći na terenu, ali su njihovi prikazi sačuvani na nekoliko fotografija s početka 20 . stoljeća.

"Kao jamstvo vrhunske autentičnosti fotografija je i u hrvatskoj etnologiji već odavna uobičajeni oblik reprezentacije $\mathrm{u}$ analizi tradicijske kulture. Tako fotografija nosi dvostruku oznaku znanstvenog sredstva i krajnjeg cilja: katkad je neizostavni dio istraživanja." (Belaj 2006: 54) Kao povijesnim dokumentom ili izvorom možemo se njome poslužiti da nam potvrdi ili nadopuni neki drugi izvor informacija. Fotografija može poslužiti kao slikovna potvrda usmenoga svjedočanstva, a u nedostatku toga ostaje kao dragocjen i ponekad i jedini izvor podataka za tradicijsko odijevanje određenoga razdoblja. Često se koristi kao ilustracija koja dokumentira temu narodne nošnje na izložbama, u katalozima i knjigama, dok u muzejskoj zbirci funkcionira kao samostalni

45 Coklin je polukružno začešljana kosa u jedan ili dva polukruga sa svake strane na čeonom dijelu.

46 Kintoši ili vitice, kako ih zovu u nekim selima, su pletenice pletene od četiri, pet ili šest struka.

47 Rogovi su dva polukružna coklina nadignuta u obliku rogova sa svake strane.

48 Roce su uobičajeni naziv za pletenice od konjske strune pletene u obliku rešetke koje su žene nosile pričvršćene na čeonom dijelu ispod marame. Istom tehnikom djevojke su plele takve pletenice od svoje kose uz perčin. U selu Biškupci takvu djevojačku pletenicu nazivaju isto rocama.

49 Rekonstrukciju frizura s fotografija izradile su lokalna frizerka i nekoliko žena iz Kulturno umjetničkog društva "Šijaci" iz Biškupaca.

50 Dječaci, mlađi muškarci i mladići na rukama su uz svečanu nošnju nosili pletene vunene narukvice s đerdanima - perlicama.

51 Ogrlice su rekonstruirane za potrebe kulturno umjetničkih društava, ali i za popunjavanje Zbirke oglavlja i nakita Gradskog muzeja Požege. 
reprezentativni muzejski predmet (Matoković 2019a: 26). Ulaskom u muzej fotografija ne mora izgubiti na važnosti obiteljske predaje i sjećanja koje se vežu uz nju. "Priča koja s njom dolazi može također obogatiti njezinu vrijednost kao izvornog dokumenta." (Ibid.) Jedna od rijetkih takvih zabilježenih priča je vezana uz nastanak fotografije (inv. br. 13850) snimljene 1917. godine u "Atelieru Wollner". ${ }^{52}$ (Sl. 11) Fotografija prikazuje mladića i djevojku u svečanoj narodnoj nošnji u kojoj prevladavaju kupovne tkanine i dijelovi građanske odjeće. Između njih na atelijerskom stolcu stoji dječak odjeven u rubinu, gaće i frosluk s džepnim satom na privjesku. Obiteljska, usmena predaja njezine nekadašnje vlasnice donosi priču o njezinu nastanku. Djevojka na fotografiji u sklopu svoje svečane odjeće na glavi nosi kupovni bijeli voštani vijenac koji je prvih desetljeća 20. stoljeća bio uobičajeni sastavni dio opreme mladenke. Međutim, na ovoj snimci prema obiteljskoj predaji mladi par predstavlja zaručnike, ${ }^{53}$ a ne mladence. Bijeli vijenac $\mathrm{u}$ ono vrijeme bio je i obilježje zaručene djevojke koja ga je nosila u sklopu svoje najsvečanije nošnje sve do udaje. ${ }^{54}$ Zaručnici su odlazeći u Požegu na fotografiranje za buduću uspomenu "poveli djevojčinog malog bratića koji je uporno zahtijevao da pođe s njima. Bio je to otac nekadašnje vlasnice fotografije. Tako je jedna fotografska uspomena na zaručnike dobila jednog dječaka i obiteljsko sjećanje na taj događaj" (Matoković 2019a: 26). Snimljene fotografije u atelijeru obično prikazuje ljude odjevene u najsvečaniju odjevnu kombinaciju koja će ih pokazati u najljepšem izdanju. Negativi Julija Kempfa također portretiraju ljude, ali često su to zatečeni ljudi na seoskoj ulici, pred crkvom, u dvorištu ili prikazuju neki određeni događaj, proslavu blagdana ili slično. (Sl. 12) Iako je vidljivo da poziraju fotografu, prema njihovoj odjeći može se zaključiti da su uhvaćeni u trenutku svakodnevnice ili slavlja. (Sl. 13) I u svakidašnjoj nošnji primjećuje se preslojavanje osnovnoga ruha kupovnim, maramama i pregačama od jeftinijih pamučnih tkanina i štofova te prodor građanskih odjevnih predmeta, kod žena bluzama, a kod muškaraca hlačama. (Sl. 14)

Osim toga Kempf dokumentira i određene događaje poput blagoslova hrane na Uskrs pred crkvom, procesije i sajmove. U skladu s tadašnjim trendom tzv. trenutne fotografije on snima neposredan trenutak i pokret, donosi fotografsku reportažu određenoga događaja, stvarnosti (usp. Skuljan 2003: 40). U toj raznolikoj velikoj grupi ljudi jasnije se uočava na njihovoj odjeći društveni i materijalni položaj pojedinaca i socijalna slojevitost seoskih stanovnika. Jedan od takvih primjera je snimka crkvene procesije u Skenderovcima iz 1911. godine. (Sl. 15) U središnjem planu, iza baldahina ${ }^{55}$ pod kojim svećenik nosi Presveti sakrament, koračaju žene i djevojke. Na pozitivu negativa u

52 S fotografijom sam se prvi put susrela kao studentica prilikom istraživanja svadbenih običaja koja je tada bila u privatnom vlasništvu. Drugi put sam je dobila na korištenje u sklopu projekta istraživanja narodnih nošnji Zapadne Slavonije kada je u međuvremenu i otkupljena za Gradski muzej Požege.

53 Kod ovakvih snimki djevojačkih oglavlja s bijelim voštanim vijencima treba biti oprezan u zaključku da li se radi o mladenki ili zaručenoj djevojci, pogotovo ako se ne zna kontekst nastanka snimke.

54 U dotadašnjim etnološkim istraživanjima do kraja 20. stoljeća bilo je poznato da je bijeli voštani vijenac dio mladenkine opreme. Ugledavši fotografiju kao studentica u sklopu istraživanja svadbenih običaja pretpostavila sam da djevojka s vijencem predstavlja mladenku. Međutim, tada sam prvi put dobila informaciju od vlasnice fotografije i svoje bake da je bijeli vijenac bio obilježje i zaručene djevojke. Potvrdu njihovog iskaza sam dobila godinama kasnije kao kustosica požeškog muzeja od još nekoliko kazivača.

55 Baldahin s Presvetim je središnje i najvažnije mjesto u procesiji, a nose ga četvorica mlađa muškarca u svečanim odijelima građanskog kroja. 
mnoštvu ženskih likova mogu se uočiti žene odjevene po secesijskoj modi, djevojke koje svojim preslojenim bijelim maramama od tila oko vrata ili bijelim fertunima ukrašenima vrpcama i volanima unose secesijska obilježja u svoju nošnju, oniska žena u skromnoj i jednostavnoj nošnji novijega tipa, žena u nošnji susjednoga novogradiškog kraja s kariranom tkanom maramom na glavi i bijelom košuljom ${ }^{56}$ opasanom vunenom pregačom ili mlada žena s okićenim bijelim bajoderom ili tinogledom ${ }^{57}$ na glavi... Svakako pri toj analizi treba uzeti u obzir kontekst u kojem su fotografije nastale, što nije uvijek jednostavno jer često nije moguće utvrditi identitet snimljenih osoba. (Burke 2003: 20)

\section{ZAKLJUČAK}

Fotografije seljaka požeškoga kraja u njihovoj tradicijskoj odjeći koje su početkom 20. stoljeća snimili Julije Kempf i fotografski "Atelier Wollner" pokazale su se važnim dokumentarnim izvorom u rekonstrukciji i istraživanju narodne nošnje. Obradom i analizom fotografija narodnih nošnji s početka 20. stoljeća nadopunjuju se i proširuju dosadašnje spoznaje iz drugih izvora, poput sačuvanih dijelova nošnji, usmenih kazivanja, etnografskih zapisa, novinskih članaka i rukopisa. Njihovim kvalitetnim digitalnim snimanjem mogu se uočiti važni detalji za proučavanje tradicijske odjeće.

Fotografije dokumentiraju jedno razdoblje i promjene koje su tada zahvatile tradicijsko odijevanje požeških seljaka gdje svjedoče o njegovoj slojevitosti. Paralelno na njima uočavamo elemente "starijega" tradicijskog odijevanja i onoga "novoga" pod utjecajem novih doseljenika i građanske kulture. Iako često korištena kao ilustracija u terenskim istraživanjima, katalozima izložbi i monografijama o tradicijskom odijevanju, i sama može biti izvor novih podataka i spoznaja o odijevanju požeških seljaka s početka 20. stoljeća. Kao takva može poslužiti u rekonstrukciji dijelova narodne nošnje, frizure i nakita, a u nedostatku drugih izvora služi kao vjerodostojan dokument za istraživanje tradicijskoga odijevanja i kićenja. Fotografija kao slikovni povijesni izvor može potvrditi rijetke pisane izvore svoga vremena. Isto tako pokazala se kao važna nadopuna i potvrda terenskim istraživanjima i usmenim kazivanjima, iako katkada može donijeti i dotada nepoznate podatke koje je potrebno dalje istraživati. Za fotografiju se govori "da govori više od tisuću riječi”, ali ako nije poznat kontekst i priča njezina nastanka, ne možemo dobiti sasvim cjelovitu sliku informacija koje pruža.

Fotografije koje su snimili Julije Kempf i "Atelier Wollner" u Požegi povijesna su slika muških i ženskih nošnji s kraja 19. i prva dva desetljeća 20. stoljeća gdje se mogu pratiti promjene i utjecaji gradske mode na tradicijsku odjeću požeških sela. Ovdje fotografija ostvaruje svoju ulogu kao dokument koji svjedoči o kulturi te kao svjedočanstvo jednoga vremena zaustavlja i prikazuje ljude, njihov izgled i odjeću, frizure, nakit i

56 Na osnovi ove odjevne kombinacije može se pretpostaviti da žena dolazi iz Cerničke župe gdje su se nosili bijeli skuti i oplećak tipa požeške, paurske nošnje.

57 Velika četvrtasta tvornička marama od bijeloga tila, nošena za svečane prilike. Nošena je dijagonalno presložena uz stariji i noviji tip ženske nošnje. Djevojke su ih nosile prebačene preko ramena i povezane na leđima u struku, a mlade udane žene u prvoj godini braka preko poculice na glavi, spuštenih krajeva naprijed na prsima ili iza na leđima. 
ukrase. Fotografije snimljene početkom 20. stoljeća predstavljaju značajan dokument onoga vremena i važan izvor podataka za povjesničare i etnologe (Šimunić 2018: 59), kako u sadašnjim tako i u budućim istraživanjima.

\section{LITERATURA I IZVORI:}

BELAJ, Melanija. 2006. "Obiteljska fotografija - analiza i interpretacija u okviru teorije predstavljanja Ervinga Goffmana”. Etnološka tribina 29: 53-69.

BURKE, Peter. 2003. Očevid: Upotreba slike kao povijesnog dokaza. Zagreb: Antibarbarus.

DOMANOVIĆ, Ivana. 2019. "Korak ispred vremena, Atelier Wollner”. U: Korak ispred vremena, Atelier Wollner (1899. - 1934.). Požega: Gradski muzej Požega, str. 3-16.

Izvješće o provedenoj digitalizaciji dijela zbirke želatinskih negativa na staklu iz Gradskog muzeja u Požegi, 2016., Dokumentacija Gradskog muzeja Požega.

KARAMAN, Igor. 1997. Požega u srcu Slavonije. Jastrebarsko: Naklada Slap.

KEMPF, Julije. 1910. Požega, zemljopisne bilješke iz okoline i prilozi za povijest slobodnog i kraljevskog grada Požege i Požeške županije. Požega: Štamparija "Hrvatske tiskare i knjižare".

KEMPF, Julije. 1996. Moja požeška sjećanja. Požega: Matica hrvatska, Ogranak Požega.

LECHNER, Zdenka. 1977. “Tekstilne rukotvorine”. U: Požega 1227. - 1977. Marijan Strbašić ur. Slavonska Požega: Skupština općine Slavonska Požega i Odbor za proslavu 750-godišnjice grada Slavonske Požege, str. 301-308.

MARINGER, Boris. 2019. “Atelier Wollner”. U: Korak ispred vremena, Atelier Wollner (1899. - 1934.). Katalog izložbe. Požega: Gradski muzej Požega, str. 27-30.

MATOKOVIĆ, Dubravka. 2019a. "Prikaz narodne nošnje na fotografijama Atelier Wollner". U: Korak ispred vremena, Atelier Wollner (1899. - 1934.). Požega: Gradski muzej Požega, str. 23-26.

MATOKOVIĆ, Dubravka. 2019b. Narodna nošnja Požeštine -Biškupci. Požega: Hrvatski sabor kulture.

PETKOVIĆ, Antun, 1977. “Migracije” U: Požeški leksikon A-Ž. Petković, Antun, ur. Slavonska Požega: Skupština općine Slavonska Požega, str. 165-166.

SCHOESER, Mary. 2009. Svijet tekstila, kratka povijest. Zagreb: Golden marketing-Tehnička knjiga.

SIMONČIĆ, Katarina Nina. 2013. "Analiza izvora u rekonstrukciji mode Zagreba s prijelaza 19. u 20. stoljeće", Tekstil 62 /11-12: 424-430.

SKULJAN, Lana. 2009. Fotografija u Istri do 1918. iz fundusa Zbirke fotografija, negativa $i$ fotografske opreme. Pula: Povijesni muzej Istre.

ŠIMUNIĆ, Ljerka. 2018. "Fotografija u funkciji eksponata, kao izvor podatka i kao autentični dokument vremena". Informatica museologica 49: 55-59. 
ŠPANIČEK, Lidija. 2019. “Cecilija Wollner (1878. - 1942.), prva modistica razglednica u Hrvatskoj”. U: Korak ispred vremena, Atelier Wollner (1899. - 1934.). Požega: Gradski muzej Požega, str. 17-22.

ŠPERANDA, Mirjana. 2015. "Donacija obitelji Kempf: Svi smo sada jedna obitelj. U povodu 150. obljetnice rođenja Julija Kempfa, 80. obljetnice smrti i 90. obljetnice Gradskog muzeja Požega”. Informatica museologica 45-46: 119-124.

TOLDI, Zvonimir. 2009. "Nošnje, posoblje, češljanje, nakit”. U: Samo staj, pa gledaj! Secesija i art deco u tradicijskoj kulturi Brodskog Posavlja. Z. Toldi, ur. Slavonski Brod: Muzej Brodskog Posavlja, str. 15-19.

VUDY, Šime. 1892. “Zašto nam gospodarstvo ne napreduje?”. Glasnik županije požeške. Požega, 12. ožujka, str. 1, 2.

Zbirka fotografija i negativa, Računalni inventarni program M++ Gradskoga muzeja Požega.

Zbirka narodnih nošnji, Računalni inventarni program M++ Gradskoga muzeja Požega.

Zbirka (ženskih) oglavlja i nakita, Računalni inventarni program M++ Gradskoga muzeja Požega. 